\title{
Chemical Constituents and Biological Activities of Genus Picrorhiza: An Update
}

\author{
V. PRAKASH* ${ }^{*}$ ANJANA KUMARI, HARPREET KAUR, M. KUMAR, S. GUPTA ${ }^{1}$ AND R. BALA ${ }^{2}$ \\ Department of Chemistry, M.M. University, Sadopur-Ambala, Haryana-134 007, ${ }^{1}$ M. M. College of Pharmacy, \\ M. M. University, Mullana, Haryana-133 203, ²Department of Chemistry, Guru Nanak Dev University, Amritsar-143 005, India
}

\section{Prakash et al.: Chemical Constituents and Biological Activities of Genus Picrorhiza}

\begin{abstract}
This review article on Picrorhiza genus comprehensively summarized the characterization, morphology, distribution, traditional uses, chemical constituents and biological activities of isolated individual constituents as well as plant extracts. It belongs to the Scrophulariaceae family, a small genera with two species, which are mainly found in Western and Eastern Himalayas at an altitude of 3000-5200 m. It has been used traditionally to cure many diseases like asthma, arthritis, cancer, diabetes, diarrhea, dyspepsia, fever, gastrointestinal problems, jaundice, urinary disorders. Its phytochemical analysis reported the presence of glycosides, aromatic esters, bis-iridoid, phenyl propenoids, alcoholic compounds and fatty acids. Chemical constituents of the genus Picrorhiza and its crude extracts with various solvents exhibit biological activities such as antimicrobial, anticancer, antiasthmatic, antidiabetic effects.
\end{abstract}

Key words: Picrorhiza, glycosides, antimicrobial, anticancer, phytochemicals

Plants and their parts have been used for medicinal uses since immemorial time. The first evidence marked on clay tablets in the cuneiform script is from Mesopotamia $2600 \mathrm{BC}$ where the recipes of drug preparation have been written ${ }^{[1-3]}$. It is a universally accepted principle that human beings and diseases are born simultaneously. Vedas ${ }^{[4]}$, Quran ${ }^{[5-7]}$, Buddhism ${ }^{[8]}$ and Bible ${ }^{[9]}$ are the religious texts that have described diseases, drugs, and therapies. The entire knowledge of Ayurveda is derived from Vedic literature. Vedic system of medicine is the root of Ayurveda and it is supposed to be the science of all aspects of life ${ }^{[10]}$. Ancient philosophy deliberates the "secret of life and beyond" for health and medicinal plants ${ }^{[11]}$. No plant of this earth is useless from a medicinal point of view ${ }^{[12]}$.

The Himalayas, a mountain range in Asia covering mainly India, Pakistan, China, Tibet, and Nepal is known as a treasure house of the medicinal plants with around 8000 species in which 1748 species are known to have medicinal value ${ }^{[13-16]}$. A majority of the rural population ( $90 \%$ ) depends upon the medicinal plants as a source of remedies ${ }^{[17-21]}$. Alone in India about 2000 tons of herb consumed annually ${ }^{[22-26]}$. Globally, the excessive use of synthetic drugs and their side effects have attracted the researchers towards herbals medicine in past years. Plants contain many different phytochemical

*Address for correspondence

E-mail: vinitprakash@gmail.com

July-August 2020 compounds that are individually effective enough to treat chronic and infectious diseases ${ }^{[27,28]}$.

The genus Picrorhiza is well known for its medicinal values since the ancient as well as modern period. There are not many reviews on Picrorhiza, except a few such as cellular differentiation, regeneration and secondary metabolite production in medicinal Picrorhiza species $^{[29]}$, reviews of its chemical constituents ${ }^{[30]}$, phytopharmacological review on genus Picrorhiza ${ }^{[31]}$, Picrorhiza kurroa: an ethnopharmacologically important plant species of the Himalayan region ${ }^{[22]}$. Therefore, there is a need to prepare an updated detailed review on the genus Picrorhiza. This review mainly deals with the isolation of plant extracts and individual chemical constituents of Picrorhiza and studies of biological activities shown by an individual chemical constituent as well as on solvent extracts carried out so far in the last decade, based upon the literature survey through PubMed, Mendeley, Ex Prisma.

\footnotetext{
This is an open access article distributed under the terms of the Creative Commons Attribution-NonCommercial-ShareAlike 3.0 License, which allows others to remix, tweak, and build upon the work non-commercially, as long as the author is credited and the new creations are licensed under the identical terms
} 


\section{Classification:}

Picrorhiza is commonly called $\mathrm{karu}^{[32]}$, while scientifically it is placed in Kingdom: Plantae; Class: Dicotiledonal; Order: Scrophulariales; Family: Scrophulariaceae; Genus: Picrorhiza; Species: kurroa, scrophulariiflora; Botanical name: P. kurroa Royal ex Benth and P. scrophulariiflora Pennel ${ }^{[31]}$.

\section{Morphology:}

The genera Picrorhiza is derived from 'picros' and 'rhiza', which means bitter root ${ }^{[33-35]}$. Genus Picrorhiza has two species namely Picrorhiza kurroa and Picrorhiza scrophulariiflora ${ }^{[36]}$. P. kurroa is smaller in height $(5-9 \mathrm{~cm})$ with smaller leaves $(7-11 \mathrm{~cm})$. The leaves of the plant are flat, oval, saw-toothed, five narrowed to a winged stalk, and sharply serrated. The flowers are white or pale purple and borne on a tall spike and its corolla is much smaller $(0.8 \mathrm{~cm})$, five-lobed to the middle, and with very much longer stamens. The rhizome is $2.5-12 \mathrm{~cm}$ long, sub-cylindrical, straight, or to some extent curved, and the external surface is coarse $^{[37-40]}$.

P. scrophulariiflora is longer than $P$. kurroa in height $(8-12 \mathrm{~cm})$ with longer leaves. The leaves of the plant are flat, oval, saw-toothed and its leaf blades are $10-14 \mathrm{~cm}$ in length. The flowers are dark blue-purple in color arising from a rosette of conspicuously serrated leaves and its corolla is $1.5 \mathrm{~cm}$. Rhizomes are 2.5-12 cm long, sub-cylindrical, straight, or to somewhat curved and the rhizomes are evanescent inside ${ }^{[37]}$.

\section{Distribution:}

P. kurroa occurs mainly in the Western Himalayas at an altitude of 3000-5000 $\mathrm{m}^{[34,41-44]}$, while P. scrophulariiflora is found mainly in the Eastern Himalayas at an altitude of 4300-5200 m. P. scrophulariiflora species of this genus is found only in Nepal ${ }^{[5,46]}$.

\section{Traditional uses:}

The World Health Organization (WHO) defined that the traditional medicine is a total sum of all knowledge and practices, which is explainable or not and it is used in diagnosis, prevention and elimination of physical, mental, or social imbalance and relying exclusively on practical experience and observation handed down from generation to generation, whether verbally or in writing ${ }^{[46]}$. Traditional knowledge is passing from generation to generation without the aid of any documentation or keeping written records. This knowledge will be lost with succeeding generations if it is not rapidly researched and recorded ${ }^{[18]}$. Therefore, its documentation is of paramount importance and urgent so that it can be preserved and conserved ${ }^{[47,48]}$. Ethnobotanical surveys are effective methods in documenting and identifying medicinal plants used in the traditional knowledge system ${ }^{[49]}$. Both the species P. kurroa and P. scrophulariiflora have been used traditionally for the treatment of a large number of diseases long before the time ${ }^{[50,51]}$. The different parts of $P$. kurroa have been used to cure various diseases. The rhizomes of $P$. kurroa are used to cure asthma, arthritis, cancer, diabetes, dyspepsia, fever, gastrointestinal problems, jaundice, leukoderma, piles, snake bite, and urinary disorders.

The seeds of $P$. kurroa are used to treat diarrhea, fever, liver, and upper respiratory tract disorders, its leaves are used to cure diseases such as bilious fever and chronic infections, and its flowers are also used for the treatment of fever and blood purification ${ }^{[11,42,52-77]}$.

Traditionally, stems of $P$. scrophulariiflora have been used to cure arthritis, asthma, choleretic, jaundice, liver disorder while its roots are useful for the treatment of bacterial infections, fever, jaundice, liver disorder, and inflammatory diseases ${ }^{[78-81]}$. P. scrophulariiflora is also used in traditional Chinese medicine for treating dysentery, jaundice and rheumatism ${ }^{[82]}$.

\section{Isolation of chemical constituents:}

During the said period of review around 53 compounds have been isolated from these 2 species of genus Picrorhiza, out of which 38 are glycosides, 6 aromatic esters, 4 bis-iridoids, 4 phenylpropanoids and an alcoholic compound. From P. kurroa, a total of 36 compounds have been isolated, which included 26 glycosides, 6 aromatic esters and 4 bis-iridoids from different parts of the plants whereas 17 compounds have been isolated from $P$. scrophulariiflora, which contained only 12 glycosides, 4 phenylpropenoids and an alcoholic compound (Table 1). The structures of these compounds are given in fig. 1 (excluding compounds reported by Sah and Varshney ${ }^{[30]}$ ).

Glycosides are formed from the combination of a hydroxyl group of a simple sugar with another compound. From the genus Picrorhiza, 8 types of glycosides have been isolated, which included iridoid glycosides (23), aromatic aldehyde glycoside (1), aromatic aldehyde diglycoside (1), diphenolic tetra glycoside (1), phenolic glycosides (5), phenylpropanoid glycoside (2), secoiridoid glycosides (2) and hydroquinone glycosides (3) from different parts of the 


\begin{tabular}{|c|c|c|c|c|c|c|}
\hline $\begin{array}{l}\text { S. } \\
\text { No. }\end{array}$ & Chemical constituents (No.) & $\begin{array}{l}\text { Plant } \\
\text { species }\end{array}$ & Plant Part & $\begin{array}{c}\text { Solvent } \\
\text { employed }\end{array}$ & $\begin{array}{l}\text { Biological } \\
\text { activities }\end{array}$ & Reference \\
\hline \multicolumn{7}{|c|}{ Glycosides } \\
\hline 1. & $\begin{array}{l}\text { [6-[(1a,1b,2,5a,6,6a)-6- } \\
\text { hydroxy-1a-(hydroxymethyl)-2,5a,6,6a- } \\
\text { tetrahydro-1bHoxireno[5,6]cyclopenta [1,3- } \\
\text { c]pyran-2-yl]oxy]-3,4,5-trihydroxyoxan-2- } \\
\text { yl] methyl-3 phenylprop-2-enoat. (1) IG }\end{array}$ & P.K. & $\begin{array}{l}\text { Rhizomes; } \\
\text { Rhizomes } \\
\text { and leaves }\end{array}$ & $\begin{array}{l}\text { Methanol; } \\
\text { Methanol: } \\
\text { water }(1: 1) \text {; } \\
\text { Ethanol and } \\
\quad \text { Water }\end{array}$ & $\begin{array}{l}\text { Anticancer } \\
\text { activity; } \\
\text { Antiarthritis } \\
\text { activity; } \\
\text { Antidiabetic } \\
\text { activity; } \\
\text { Hepatoprotective } \\
\text { activity. }\end{array}$ & $\begin{array}{l}{[75,84,86,88} \\
\quad 89,90,92]\end{array}$ \\
\hline 2. & $\begin{array}{c}\text { [2-(hydroxymethyl)-10-[3,4,5-trihydroxy- } \\
\text { 6-(hydroxymethyl)oxan-2-yl]oxy-3,9- } \\
\text { dioxatricyclo[4.4.0.02,4]dec-7-en-5-yl] } \\
\text { 4-hydroxy-3-methoxybenzoate. (2) IG } \\
\text { [5-hydroxy-10-[3,4,5-trihydroxy-6- } \\
\text { (hydroxymethyl)oxan-2-ylloxy-3,9- }\end{array}$ & P.K. & $\begin{array}{l}\text { Rhizomes; } \\
\text { Rhizomes } \\
\text { and leaves }\end{array}$ & $\begin{array}{l}\text { Methanol; } \\
\text { Methanol: } \\
\text { water; } \\
\text { Methanol } \\
\text { and Water; } \\
\text { Ethanol and } \\
\text { Water }\end{array}$ & $\begin{array}{l}\text { Antiarthritis } \\
\text { activity; } \\
\text { Antidiabetic } \\
\text { activity; } \\
\text { Hepatoprotective } \\
\text { activity. }\end{array}$ & $\begin{array}{l}{[75,84,88} \\
89,90,92]\end{array}$ \\
\hline 3. & $\begin{array}{c}\text { dioxatricyclo[4.4.0.0 } 2 \text {,4 }] \text { dec-7-en-2-yl] } \\
\text { methyl 4-hydroxy-3-methoxybenzoate. (3) } \\
\text { IG }\end{array}$ & P.K. & Rhizomes & $\begin{array}{l}\text { Ethanol; } \\
\text { Methanol }\end{array}$ & $\begin{array}{l}\text { Antimicrobial } \\
\text { activity; } \\
\text { Anticancer } \\
\text { activity. }\end{array}$ & {$[85,86]$} \\
\hline 4. & $\begin{array}{c}\text { [3,4,5-trihydroxy-6-(hydroxymethyl)oxan- } \\
\text { 2-yl] 3-methoxy-4-[3-phenylprop-2-enoyl] } \\
\text { oxybenzoatedihydrate. (4) IG }\end{array}$ & P.K. & Rhizomes & $\begin{array}{l}\text { Water; } \\
\text { Methanol }\end{array}$ & $\begin{array}{l}\text { Antidiabetic } \\
\text { activity; } \\
\text { Antimicrobial } \\
\text { activity }\end{array}$ & {$[86,87]$} \\
\hline 5. & $\begin{array}{l}\text { 1-(4-hydroxy-3-methoxyphenyl)ethanone. } \\
\text { (5) IG }\end{array}$ & P.K. & Rhizomes & $\begin{array}{l}\text { Ethanol and } \\
\text { Water }\end{array}$ & $\begin{array}{l}\text { Antidiabetic } \\
\text { activity. }\end{array}$ & {$[90]$} \\
\hline 6. & Vanillin-a-D-glucopyranoside. (6) AAG & P.K. & Rhizomes & Methanol & $-\cdots-$ & [91] \\
\hline 7. & 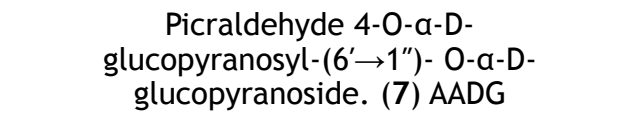 & P.K. & Rhizomes & Methanol & $-\cdots-\cdot$ & [91] \\
\hline 8. & Picrorhizaoside-A. (8) IG & & & & & \\
\hline 9. & Picrorhizaoside-B. (9) IG & & & & & \\
\hline 10. & Picrorhizaoside-C. (10) IG & & & & & \\
\hline 11. & Picrorhizaoside-D. (11) IG & P.K. & Rhizomes & Methanol & $\begin{array}{l}\text { Hyaluronidase } \\
\text { inhibitory activity }\end{array}$ & [110] \\
\hline 12. & Picrorhizaoside-E. (12) IG & & & & & \\
\hline 13. & Picrorhizaoside-F. (13) IG & & & & & \\
\hline 14. & Picrorhizaoside-G. (14) IG & & & & & \\
\hline & $\begin{array}{c}\text { 3-methoxy-4-hydroxyphenyl-n-butanyl-a-O- } \\
\text { D-glucopyranosyl-(6a } \rightarrow 1 b)-a-\end{array}$ & & & & & \\
\hline 15. & $\begin{array}{l}\text { O-D-glucopyranosyl- }(6 b \rightarrow 1 c)-a-0- \\
\text { D-glucopyranosyl- }(6 c \rightarrow 1 d)-a-0-D- \\
\text { glucopyranosyl-4d- }\end{array}$ & P.K. & Rhizomes & Methanol & $-\cdots-\cdot$ & [91] \\
\hline & $\begin{array}{c}\text { 3'-methoxy-4'-hydroxyphenyl-n-pent-7',9'- } \\
\text { dien-11'-oate. (15) DPTG }\end{array}$ & & & & & \\
\hline $\begin{array}{l}16 . \\
17 .\end{array}$ & $\begin{array}{c}\text { 3-phenylprop-2-enoic acid. (16) IG } \\
\text { 3-(4-hydroxy-3-methoxyphenyl)prop-2- } \\
\text { enoic acid. (17) IG }\end{array}$ & & & & & \\
\hline 18. & $\begin{array}{l}\text { 6-Hydroxy-1a-(hydroxymethyl)- } \\
\text { 1a,1b,2,5a,6,6a-hexahydrooxireno[4,5] } \\
\text { cyclopenta[1,2-c]pyran-2-yl 6-O-[(2E)-3-(4- } \\
\text { hydroxy-3-methoxyphenyl)-2-propenoyl]-B- } \\
\text { D-glucopyranoside. (18)IG }\end{array}$ & P.K. & Rhizomes & $\begin{array}{l}\text { Hydro- } \\
\text { alcoholic }\end{array}$ & $-\cdots-\cdot$ & [92] \\
\hline 19. & Scrophuloside. (19) IG & & & & & \\
\hline 20. & Veronicoside. (20) IG & & & & & \\
\hline
\end{tabular}


www.ijpsonline.com

$\begin{array}{lc}\text { 21. } & \text { Abeloside A. (21) IG } \\ \text { 22. } & \text { Abeloside B. (22) IG } \\ \text { 23. } & \text { Sylvestroside IV dimethyl acetal. (23) IG } \\ \text { 24. } & \text { Sweroside. (24) IG } \\ \text { 25. } & \text { 8-Epi-loganin. (25) IG } \\ \text { 26. } & \text { 8-Epi-loganic acid. (26) IG } \\ \text { 27. } & \text { 2-(3,4-dihydroxyphenyl)-3,4-dihydro-2H } \\ & \text { chromene-3,5,7-triol. PG } \\ \text { 28. } & \text { 2-(3,4-dihydroxyphenyl)-5,7- } \\ \text { 29. } & \text { dihydroxychromen-4-one. PG } \\ 30 . & \text { Scroside G. PG } \\ & \text { 7 -Hydroxy-coumarine. (27)PG } \\ 31 . & \text { Cinnamic acid. (28) PG } \\ 32 . & \text { Scroside H. (29)PPG } \\ 33 . & \text { Scroside I. (30)PPG } \\ 34 . & \text { picrogentioside II. (31)SIG } \\ 35 . & \text { picrogentioside D. (32)SIG } \\ 36 . & \text { Hebitol III. (33)HQG } \\ 37 . & \text { Scrophuloside C. (34)HQG } \\ 38 . & \text { Scrophuloside D. (35)HQG } \\ & \end{array}$
P.K. Stems n- Butanol $\quad-\cdots-$
P.S. Rhizomes 95\% Ethanol

P.S. Rhizomes n-Butanol

$\begin{array}{ccc}\text { P.S. } & \text { Roots } & \text { Ethanol } \\ \text { P.S. } & \text { Roots } & \text { Ethanol } \\ \text { P.S. } & \text { Roots } & \text { Methanol } \\ \text { P.S. } & & \text { Methanol } \\ & \text { Roots } & \end{array}$

\section{Aromatic Ester}

39. 3- Methoxy-4-decanoxy benzoic acid. (36)

40 3-Methoxy-4-tetradecanoxy-phenyl npent7,9 -diene-11-al. (37)

41. 3- Methoxy-4-dodecanoxy- phenyl-n-pent-

P.K. Rhizomes

Macerated

[100]
42. 3-Methoxy-4-dodecanoxy phenyl- $n$-pent- 7,9-dien-11-al. (39)
43. 3-Methoxy-4-tetradecanoxy-phenyl $n$-pent- 7,9 -diene-11-al. (40) 3-Methoxy-4-

P.K. Rhizomes Methanol

44.

decanoxy benzoic acid. (41)

\section{Bis-iridoid}

45. Saungmaygaoside A. (42)

46. Saungmaygaoside B. (43)

47. Saungmaygaoside C. (44)

48. Saungmaygaoside D. (45)

P.K. Stems n- Butanol $\quad-\cdots$

$49 . \quad$ Luteolin -7-O-B-D-glucoside.

50. Gallic acid.

51. Isoferulic acid.

52. Vanillic acid

\section{Phenylpropenoids}

P.S.

Rhizomes 95\% Ethanol

\section{Alcoholic compounds}

53.

Hexacosanol.

P.S. Rhizomes 95\% Ethanol

$[30,97]$

P.K.-Picrorhizakurroa, P.S.- Picrorhizascrophulariiflora, IG- Iridoid glycoside, AAG-Aromatic aldehyde glycoside, AADG- Aromatic aldehyde diglycoside, DPTG-Diphenolic tetra glycoside, PG- Phenolic glycoside, PPG-Phenylpropenoid glycoside, SIG- Secoiridoid glycoside, HQGHydroquinone glycoside

Picrorhiza plant. In P. kurroa there were 26 glycoside compounds (1-26), reported from the different parts of a plant like rhizomes, leaves and stems using different solvents like methanol, ethanol, n-butanol, chloroform, water, and methanol:water $(1: 1)^{[75,83-93]}$ while in P. scrophulariiflora there are 12 glycosides (27-35), which have been reported from the different parts viz. roots, leaves and stems using different solvents like ethanol, butanol, (95\%) and ethyl acetate ${ }^{[29,30,83,91,94-99]}$.

In aromatic esters, ester linkage is bonded directly to an aromatic system. Only from the roots of P. kurroa species 6 (36-41) aromatic ester have been isolated with 


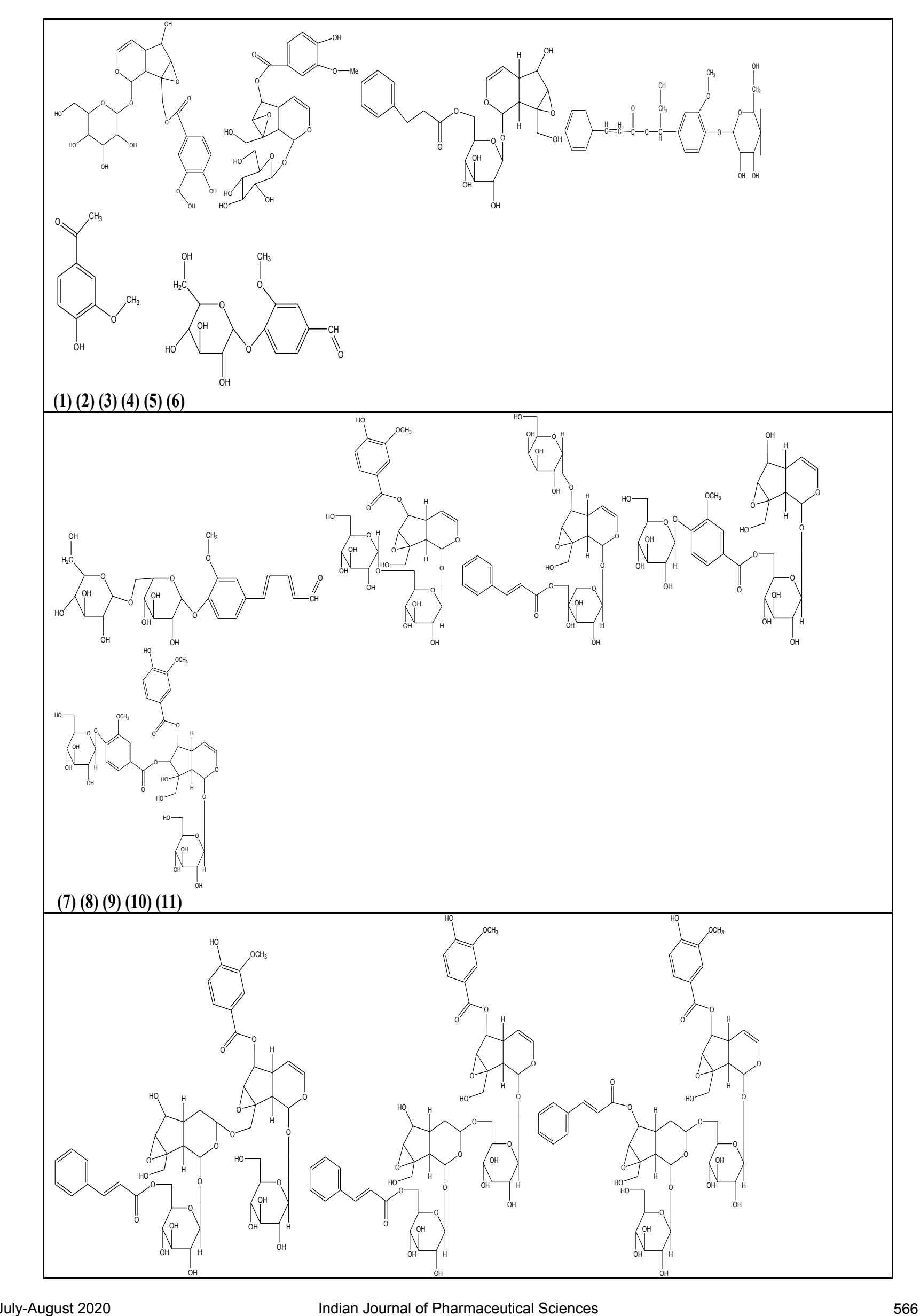


www.ijpsonline.com

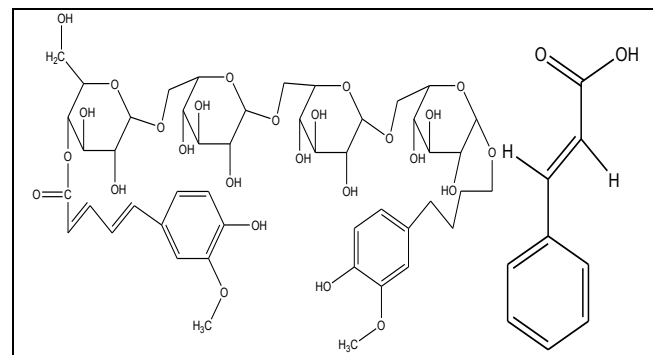

(12) (13) (14) (15) (16)
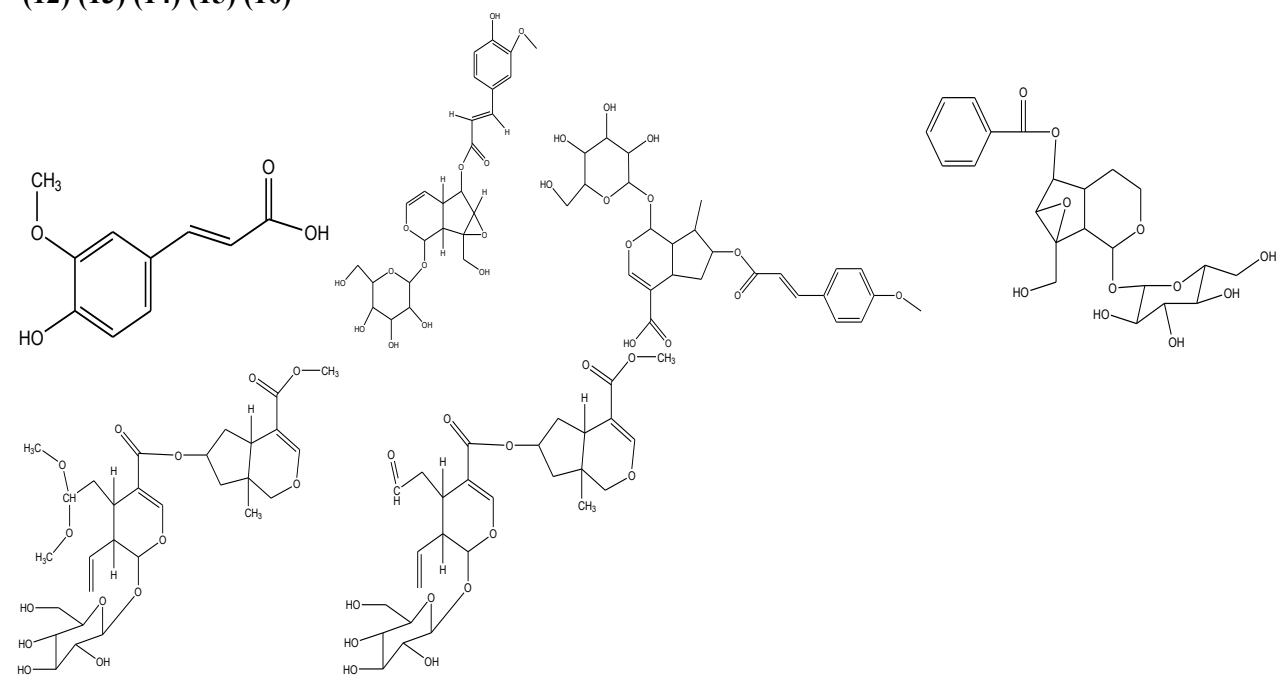

(17) (18) (19) (20) (21) (22)
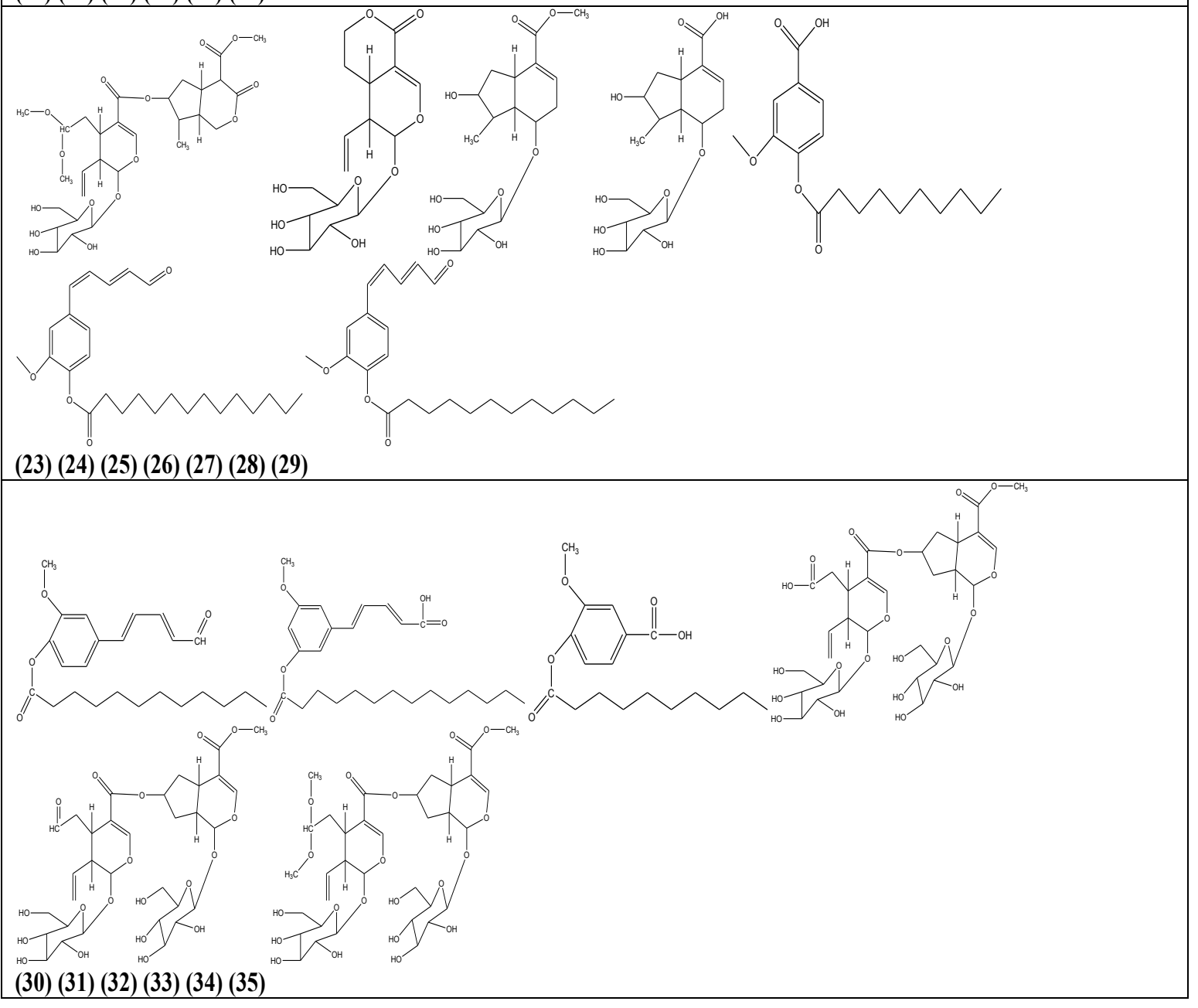

567

Indian Journal of Pharmaceutical Sciences

July-August 2020 


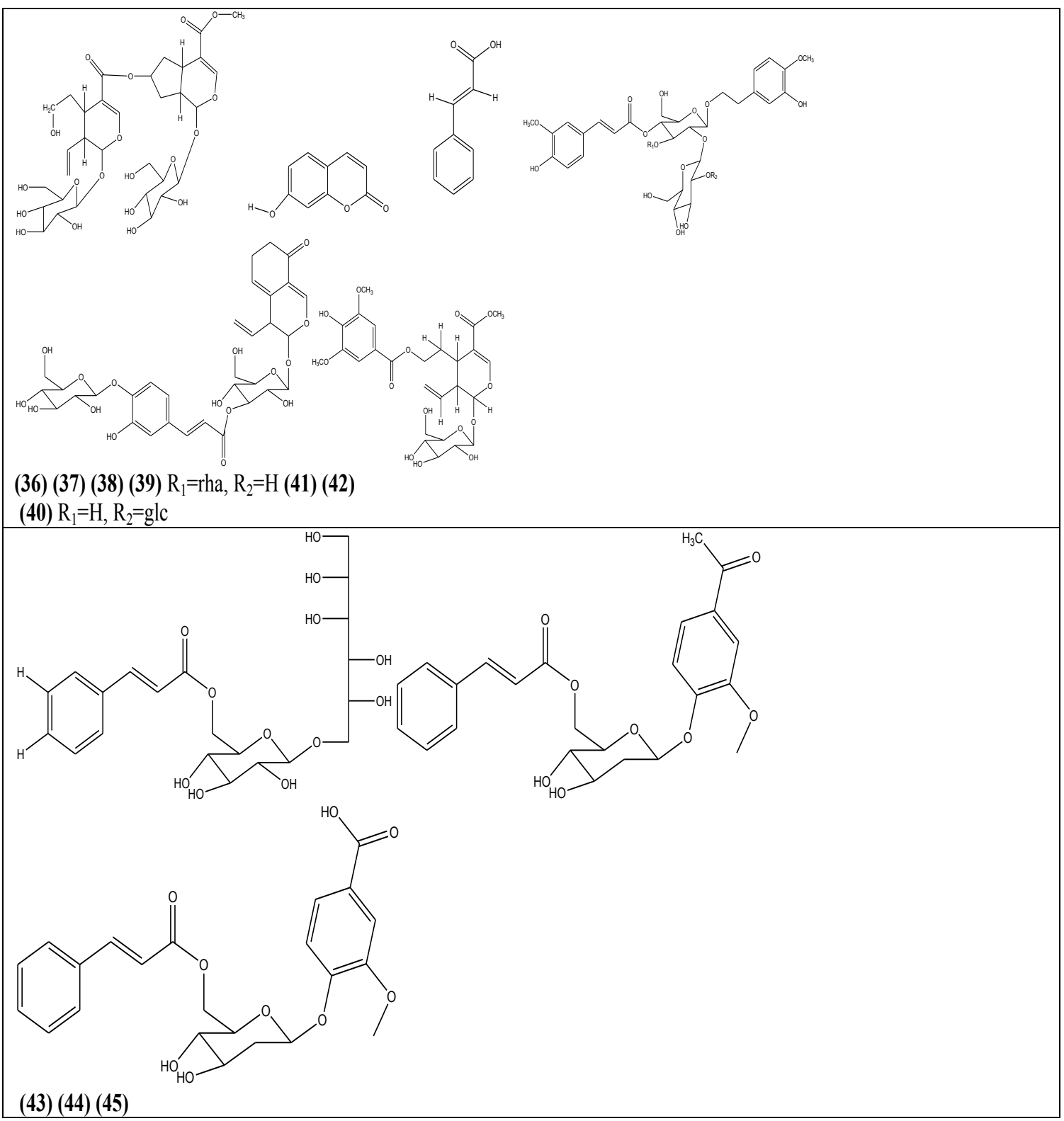

Fig. 1: Structures of isolated chemical compounds from genus Picrorhiza

water and methano ${ }^{[91,100]}$. In case of bis-iriodids, 2 units are connected by a 1,3-dioxane group. Four bis-iriodids (42-45) have been isolated from the stems of P. kurroa with n-butanol ${ }^{[93]}$. From the roots of $P$. scrophulariiflora four phenylproponoid compounds have been isolated using $(95 \%)$ ethanol as a solvent ${ }^{[30,97]}$.

Alcohols are organic compounds that contain at least one hydroxyl functional group bound to their aliphatic or aromatic substructure. One alcoholic compound has been isolated from the roots using ethanol as a solvent ${ }^{[30,97]}$. In the genus, Picrorhiza main phytochemical constituents are glycosides, which have been mainly isolated from rhizomes. The chemistry of glycosides from leaves, seeds, fruits and stems need to be explored.

\section{Phytochemical analysis:}

Many researchers used different analytical techniques like UV/Vis, IR, GC-MS, GC-FID, LC-MS, NMR, HPLC, HPTLC, UPLC, for the identification and characterization of new compounds from the genus Picrorhiza. A brief summary of Picrorhiza species using different analytical techniques are shown in Table 2 .

\section{Biological activities:}

A wide range of biological activities of isolated chemical constituents and plant extracts, like antimicrobial ${ }^{[85]}$, hepatoprotective ${ }^{[92]}, \quad$ antioxidant activity ${ }^{[101]}$, anticancer $^{[86,102]}$, antiarthritic ${ }^{[88]}$ antidiabetic ${ }^{[87]}$, 
TABLE 2: PHYTOCHEMICAL ANALYSIS ON GENUS PICRORHIZA

\begin{tabular}{|c|c|c|c|c|c|c|}
\hline $\begin{array}{l}\text { Sr. } \\
\text { no. }\end{array}$ & Plant species & Part of plant & $\begin{array}{c}\text { Solvent used for } \\
\text { extraction }\end{array}$ & $\begin{array}{c}\text { Analytical } \\
\text { Technique used }\end{array}$ & Result & References \\
\hline 1. & P. kurroa & Rhizomes & Methanol & HPTLC & $\begin{array}{l}\text { Yield of extract is } \\
40.63 \% \text { (Rf } 0.24 \text { ) }\end{array}$ & [117] \\
\hline 2. & P. kurroa & Rhizomes & Methanol & HPTLC & $\begin{array}{l}\text { Picroside-1 (Rf 0.51) } \\
\text { and kutkoside } \\
\text { (Rf 0.63) }\end{array}$ & [118] \\
\hline 3. & P. kurroa & Rhizomes & Ethanol:water & HPLC-UV & $\begin{array}{l}\text { Picroside-1: } \\
\text { 3.30\%(w/w) } \\
\text { Picroside-2: } \\
4.90 \%(w / w)\end{array}$ & [119] \\
\hline 4. & P. kurroa & Rhizomes & Diethyl ether & LC-ESI-MS/MS & $\begin{array}{l}\text { cinnamic acid, ferulic } \\
\text { acid, kuttoside, } \\
\text { picroside-I, picroside- } \\
\text { II, picroside-III, } \\
\text { scrophuloside-A, and } \\
\text { veronicoside. }\end{array}$ & [92] \\
\hline 5. & P. kurroa & Rhizomes & Ethanol:water & HPLC & $\begin{array}{l}\text { Picroside-1: } \\
\text { 9.57\%(w/w) } \\
\text { Picroside-2: } \\
4.30 \%(w / w)\end{array}$ & [90] \\
\hline 6. & P. kurroa & $\begin{array}{l}\text { Rhizomesand } \\
\text { leaves }\end{array}$ & Methanol:water & HPLC & $\begin{array}{l}\text { Picroside-1: } \\
\text { 98.3\%(w/w) } \\
\text { Picroside-2: } \\
101.3 \%(w / w)\end{array}$ & [89] \\
\hline 7. & P. kurroa & Roots & 70\% Ethanol & LC-ESI-MS/MS & $\begin{array}{l}\text { Picroside III Apocynin } \\
\text {, Pikuroside, Picroside } \\
\text { IV, Vanillic acid , } \\
\text { Picroside II, Kutkoside, } \\
\text { Picroside I }\end{array}$ & [120] \\
\hline 8. & P. kurroa & Rhizomes & Ethanol & ILUAE & $\begin{array}{c}\text { picroside I: } 2.84 \% \\
\text { picroside II: } 3.57 \% \\
\text { 6-O-E-feruloyl } \\
\text { catalpol:2.20\% }\end{array}$ & [121] \\
\hline 9. & P. kurroa & Rhizomes & $\begin{array}{c}\text { Ethanol: } \\
\text { water (mother } \\
\text { extract) further } \\
\text { fractionated } \\
\text { using hexane,n- } \\
\text { butanol, acetone, } \\
\text { methanol and } \\
\text { water }\end{array}$ & HPTLC & $\begin{array}{c}\text { Mother extract: } \\
(25.6 \% \mathrm{w} / \mathrm{w}), \text { hexane } \\
(9 \% \mathrm{w} / \mathrm{w}), \text { DCM } \\
(31 \% \mathrm{w} / \mathrm{w}), \text { n-butanol } \\
(23 \% \mathrm{w} / \mathrm{w}), \text { acetone } \\
(11 \% \mathrm{w} / \mathrm{w}), \text { methanol } \\
(16 \% \mathrm{w} / \mathrm{w}), \\
\text { and water }(7 \% \mathrm{w} / \mathrm{w}) \text {. } \\
\text { Cucurbitacin B } \\
\text { Cucurbitacin D } \\
\text { Cucurbitacin E } \\
\text { Betulinic acid } \\
\text { Picroside } 2 \\
\text { Apocynin }\end{array}$ & [102] \\
\hline 10. & P. scrophulariiflora & Fruits & Ethanol & UPLC & $\begin{array}{l}\text { Apocynin,Androsin, } \\
\text { Picroside-1, } \\
\text { Picroside-2, } \\
\text { Picroside-3 }\end{array}$ & [122] \\
\hline 11. & $\begin{array}{l}\text { P. kurroa and } P . \\
\text { scrophulariiflora }\end{array}$ & Roots & Methanol & HPTLC & $\begin{array}{c}\text { Comparing Picroside-1 } \\
\text { and Picroside-2 from } \\
\text { two different species } \\
\text { of picrorhiza } \\
\text { Picroside-1(kurroa): } \\
1.258 \% \\
\text { Picroside-1 } \\
\text { (scrophulariiflora): } \\
1.611 \% \\
\text { Picroside-2(kurroa): } \\
0.481 \% \\
\text { Picroside-2 } \\
\text { (scrophulariiflora): } \\
0.613 \%\end{array}$ & [123] \\
\hline
\end{tabular}


immunomodulating ${ }^{[103,104]}$ have been reported either from the whole plant or specific homogenized parts to prove its medicinal importance (Table 3 and 4).

Iridoid glycosides (3-4) isolated from the rhizomes of P. kurroa have shown good antimicrobial activity (cupplate method) against Gram-positive bacteria, Bacillus subtilis, Staphylococcus aureus, Micrococcus luteus, Gram-negative bacteria, Pseudomonas aeruginosa, Escherichia coli and fungal strains such as Aspergillus niger, Candida albicans and Malasseiza furfur ${ }^{[85,87]}$.

The extract prepared using ethanol from the leaves of $P$. kurroa shown antimicrobial activity against the strains of Staphylococcus, Pseudomonas, and E. coli using the agar well diffusion method, and antifungal activity against the fungal strain viz Candida albicans, Candida tropicalis, Trichophyton rubrum, and Penecillium marneff ${ }^{[105]}$.

Iridoid glycoside (5) extracted from rhizome inhibited tumor invasion and migration of MCF-7 cells ${ }^{[86]}$. The rhizome extract of Picrorhiza has shown cytotoxicity in XTT assay in MDA-MB-435S (human breast carcinoma), Hep3B (human hepatocellular carcinoma), and PC-3 (human prostate cancer) cell lines ${ }^{[101]}$. Mallick et al.$^{[102]}$ studied the anticancer activity of the hydroalcoholic extract of P. kurroa and its fractions in breast cancer and cervix cancer cell lines. Oral administration of dichloromethane fraction significantly reduced tumor volume, tumor weight, and percent packed cell volume at a dose of $50 \mathrm{mg} / \mathrm{kg}$, as compared with toxic control group.

Iridoid glycosides (5) extracted with water from the rhizomes of $P$. kurroa have shown antidiabitic activity. Compound (1) was orally administered to streptozotocin-induced diabetic rats at the doses of 100 and $200 \mathrm{mg} / \mathrm{kg} /$ day for 14 consecutive days. Plasma insulin levels were measured and the pancreas of the rat was subjected to histopathological investigations. There was evidence of regeneration of $\beta$-cells of pancreatic islets of picrorhiza extract-treated group in histopathological examinations. It increased the insulin-mediated translocation of glucose transporter from the cytosol to plasma membrane or increased glucose transporter type- 4 appearance, which in turn facilitated glucose uptake by skeletal muscles in diabetic rats ${ }^{[87]}$. Aqueous ethanol extract of P. kurroa rhizomes demonstrated antibiabetic activity. Treatment with P. kurroa rhizomes extract (100 and $200 \mathrm{mg} / \mathrm{kg}$ ) for $30 \mathrm{~d}$ significantly decreased high blood glucose and restored the normal levels of serum biochemistry ${ }^{[90]}$.
Saponin and flavonoids have been isolated from ethanol extract of root of this plant, which exhibited antiasthmatic activity in bronchoconstriction and induced airway obstruction method. These saponins have been shown to possess mast cell stabilizing while flavonoids have been reported to possess smooth muscle relaxant and bronchodilator activity ${ }^{[106]}$.

The ethanol extract of $P$. kurroa leaves were tested on a rat model of anemia induced by intraperitoneal injection of phenylhydrazine at $40 \mathrm{mg} / \mathrm{kg}$ for $2 \mathrm{~d}$. The extract was given orally to the rats previously treated with phenylhydrazine at 100 and $200 \mathrm{mg} / \mathrm{kg} / \mathrm{d}$, resulted in the increased concentration of hemoglobin, red blood cell number, hematocrit, and reticulocytes rate ${ }^{[107]}$.

Methanol extract of rhizomes of $P$. kurroa showed antioxidant activity in the superoxide anion radical scavenging method ${ }^{[108]}$. Antioxidant activity of the methanol extract was carried out using the radical scavenging assays (DPPH and $\mathrm{OH}$ ), ferric reducing antioxidant property and thiobarbituric acid assay for testing inhibition of lipid peroxidation ${ }^{[101]}$.

Kumar et al. 2016 studied the hydroalcoholic extract of rhizomes of P. kurroa, which showed antiarthritic activity. Additionally, $P$. kurroa rhizome extract significantly inhibited the expression of degrading enzymes, matrix metalloproteinases-3, and matrix metalloproteinases- 9 in arthritic rats ${ }^{[88]}$. The methanol root extract of $P$. kurroa showed antitrypanosomal activity. It was carried out on a Vero cells and there was a complete kill of trypanosomes ${ }^{[109]}$. Picrorhizaosides D $\left(4, \mathrm{IC}_{50} 43.4 \mu \mathrm{M}\right)$ and $\mathrm{E}(5,35.8 \mu \mathrm{M})$ have shown strong hyaluronidase inhibitory activity ${ }^{[110]}$.

Hydroalcoholic extract of rhizomes of $P$. kurroa demonstrated hepatoprotective activity at the dose levels of 50 and $100 \mathrm{mg} / \mathrm{kg}$ exemplified by significant restoration of liver enzyme levels and the antioxidant enzymes close control. Picrorhiza kurroa hydroalcoholic extract has ameliorative activity from tissue damage against induced hepatotoxicity ${ }^{[92]}$.

Scrocaffeside A, a compound extracted from rhizomes of $P$. scrophulariiflora has shown immunomodulatory activity against spleen cell suspension of mice. Scrocaffeside A between 5 and $125 \mu \mathrm{g} / \mathrm{ml}$ stimulated proliferation of splenocytes and their response to polyclonal $\mathrm{T}$ cell mitogen concanavalin $\mathrm{A}$ and lipopolysaccharide ${ }^{[111]}$.

Water extract of dried powdered rhizomes of P. scrophulriiflora, was given orally in doses of 20 , 40 , and $80 \mathrm{mg} / \mathrm{kg} / \mathrm{d}$ for $4 \mathrm{w}$ to rats fed with high- 
TABLE 3: BIOLOGICAL ACTIVITIES OF ISOLATED CHEMICAL CONSTITUENTS

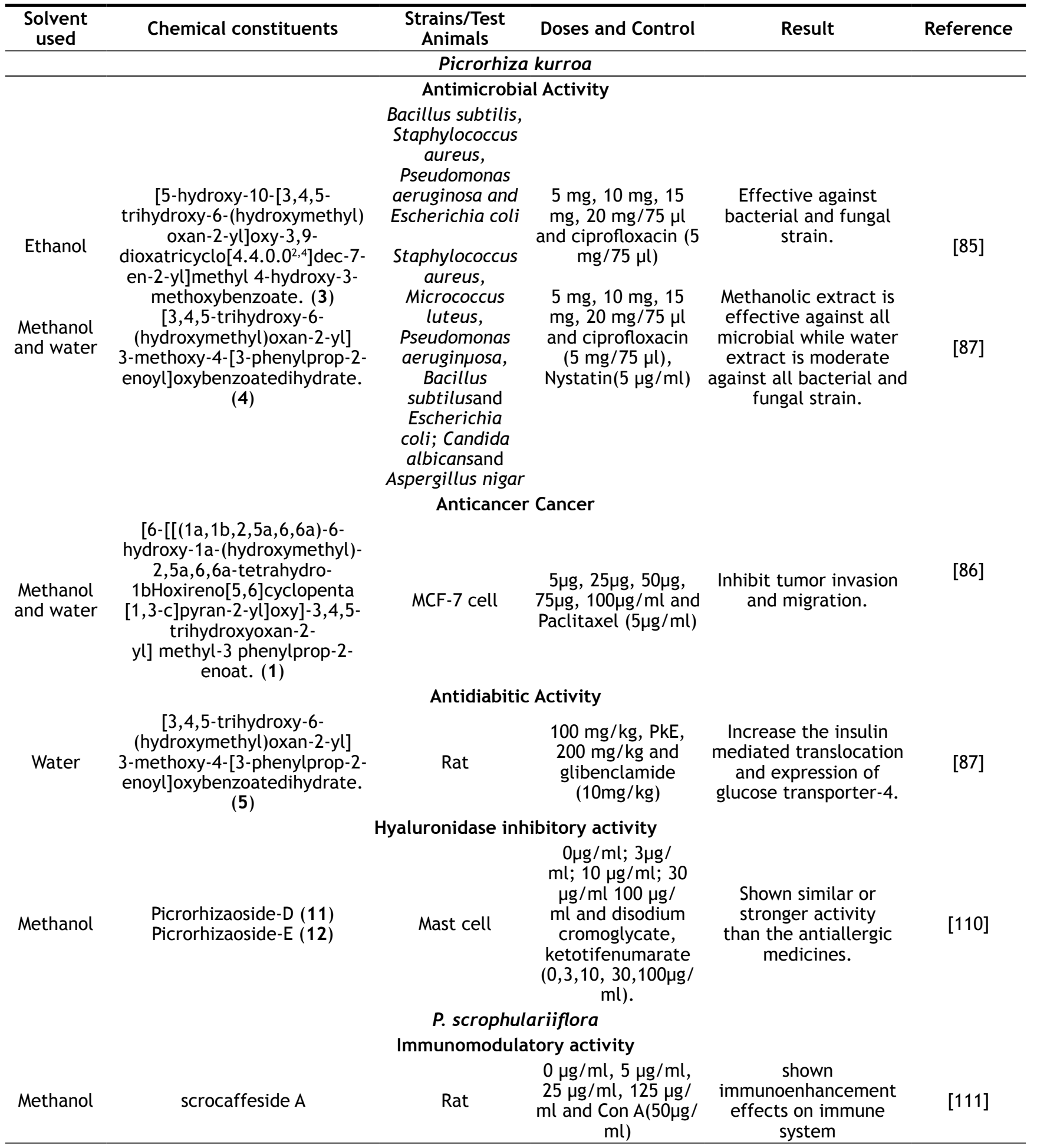

fat and high-sugar diet for $8 \mathrm{w}$ to establish nonalcoholic steatohepatitis showed antifatty liver effect. Its mechanism appeared to be the regulation of lipid metabolism and reduction of insulin resistance, through inhibition of oxidative stress and inflammation ${ }^{[12-123]}$.

Most of the biological activities have been studied extensively on $P$. kurroa as compared to $P$. scrophulariiflora as per the available literature, however, few biological activities, which have been reported were antimicrobial, high metabolic potential, immunomodulation, and therapeutic effect. There is an urgent need to explore the full potential of P. scrophulariiflora's biological activities.

\section{Future scope:}

Traditionally rhizomes of $P$. kurroa have been used to cure a liver disorder, fever, lowering sugar level, cancer, asthma, jaundice, malnutrition, urinary 


\begin{tabular}{c}
\hline Solvent used \\
\hline \\
\hline Ethanol; methanol \\
Anticancer activity \\
Methanol and water \\
Ethanol: Water (mother \\
extract) further \\
fractionated using \\
n-hexane,dichloromethane, \\
butanol, acetone, methanol \\
and water
\end{tabular}

Water and ethanol

Ethanol

Ethanol

Methanol and water

Methanol

Water and Ethanol

Strains/test animals

Picrorhiza kurroa

Antimicrobial Activity

Staphylococcus aureus,

Pseudomonoas aeruginosa,

Bacillus subtilus and E.coli;

Candida albicans, Candida

tropicalis, Trichophyton

rubrum, Aspergillus niger

and Penecillium marneffi

$10,25,50,100 \mathrm{mg} / \mathrm{ml}$ and $\quad \begin{aligned} & \text { Effective against } \\ & \text { all the selected }\end{aligned}$ ciprofloxacin $(5 \mu \mathrm{g} / \mathrm{ml}), \quad$ bacterial and fungal
Nystatin $(5 \mu \mathrm{g} / \mathrm{ml})$

strain.

MDA-MB-435S, Hep3B and PC-3 cells

$15.625,31.25,62.5$ and

$125 \mu \mathrm{g} / \mathrm{ml}$ and XTT (0.6 To induce apoptosis $\mathrm{mg} / \mathrm{ml}$ )

3.9, 7.8, 15.6, Dichloromethane

MCF-7, MDA-MB 231 and $31.2,62.5,125,250$, and fraction of $P$. kurroas HeLa, SiHa cell lines $500 \mu \mathrm{g} / \mathrm{ml}$ and MTT (5mg/ $\mathrm{ml})$

hown effective anticancer activity

Antidiabetic activity

Rat

100 and $200 \mathrm{mg} / \mathrm{kg}$ and glibenclamide $10 \mathrm{mg} / \mathrm{kg}$

\section{Antiasthmatic Activity}

$$
25 \mathrm{mg} / \mathrm{kg}
$$

Guinea pig

And salbutamol (0.2mg/ $\mathrm{kg})$

Antianemic activity

Rat

$100 \mathrm{mg} / \mathrm{kg} /$ day and $200 \mathrm{mg} / \mathrm{kg} /$ day and phenylhydrazine $(40 \mathrm{mg}$ / $\mathrm{kg}$ )

\section{Antioxidant activity}

Rat

$0.5 \mathrm{ml}$ and EDTA

Single cell of hepatocytes

$0.7 \mathrm{ml} / \mathrm{kg}$ and without $\mathrm{P}$. kurroa extract $(0.7 \mathrm{ml} / \mathrm{kg})$

\section{Antiarthritis activity}

Rat

$2 \mathrm{~mL} / \mathrm{kg}$ and Indomethacin

(3 mg/kg) increase the number
Helps in b-cell regeneration with enhanced insulin production and antihyperglycemic effects.

Reduce the inhibition of histamine and acetylcholine.

Increase the concentration of haemoglobin and of red blood cells

Methanolic extract is less efficient as compared to water in the scavenging of the radicals. Elevated the malondialdehyde levels, decreased superoxide dismutase levels, glutathione levels and oxidative stress.

Normalize redox status of synovium, suppression of pro-inflammatory cytokines, angiogenesis.

\section{Antitrypanosomal Activity}


www.ijpsonline.com

\begin{tabular}{|c|c|c|c|c|}
\hline Methanol & Rat & $\begin{array}{l}250 \mathrm{mg} / \mathrm{kg} \text { and } 1 \% \text { gum } \\
\text { acacia orally }(2 \mathrm{~mL} / \mathrm{kg})\end{array}$ & $\begin{array}{l}\text { Reduction and killing } \\
\text { of trypanosomes. }\end{array}$ & [109] \\
\hline \multicolumn{5}{|c|}{ Hepatoprotective activity } \\
\hline Ethanol and Water & Rat & $\begin{array}{c}400 \text { to } 1500 \\
\mathrm{mg} / \text { day and without } \\
\text { extract }\end{array}$ & $\begin{array}{l}\text { Significant } \\
\text { restoration of liver } \\
\text { enzyme level. }\end{array}$ & [92] \\
\hline \multicolumn{5}{|c|}{$\begin{array}{l}\text { P. scrophulariiflora } \\
\text { Therapeutic effect }\end{array}$} \\
\hline Water & Rat & $\begin{array}{l}20,40 \text { and } 80 \mathrm{mg} / \mathrm{kg} / \mathrm{d} \\
\text { and CMC }(0.5 \%)\end{array}$ & $\begin{array}{c}\text { Significantly } \\
\text { decreased total } \\
\text { cholesterol and } \\
\text { triglycerides assay } \\
\text { in liver tissue } \\
\text { and increased } \\
\text { the Superoxide } \\
\text { dismutase activity. }\end{array}$ & [112] \\
\hline
\end{tabular}

disorder, leukoderma, snake bite, piles, and rheumatic diseases. To verify the credibility of traditional uses, biological activities of rhizomes are yet to be tested in the areas of leukoderma, snake bite, and hemorrhoids. Similarly, the seeds and flowers of $P$. kurroa have been used traditionally to treat liver and upper respiratory tract disorders, fever, dyspepsia, chronic diarrhea, and blood purification but there is not much supporting data has been generated. Several traditional uses have been recorded to cure a liver disorder, choleretic, joint pain, asthma, jaundice, arthritis, and bacterial infection from the stems of $P$. scrophulariiflora but no scientific study has been carried out in this regard either.

In P. kurroa there are 29 chemical constituents (610,13-26,36-45), which have not been tested for any biological activities. Similarly, 9 chemical constituents (27-35) are isolated from $P$. scrophulariiflora but none were assessed for biological activities. Some biological activities of the genus Picrorhiza that differ from traditional uses are antianemic activity, antitrypanosomal activity, and high metabolic activity. Only some biological activities have buttressed traditional uses such as antimicrobial, hepatoprotective activity, antiasthmatic activity, arthritis activity, anticancer activity, antidiabetic activity.

Phytochemical studies on the genus picrorhiza have revealed at least 53 compounds in the last decade while the biological activities have been carried out on 8 compounds. These studies reveal antimicrobial, anticancer, antidiabetic, hyaluronidase inhibitory, immunomodulatory activities. On the basis of literature, it could be concluded that the rhizomes possessed a good profile of chemical constituents and biological activities. However more studies are required to explore about $P$. scrophulariiflora.

\section{Acknowledgments:}

Authors would like to thank Maharishi Markandashwar Educational Trust, Sadopur-Ambala (Haryana), India for their support in all respect.

\section{Conflict of Interest:}

The authors declare that they have read the policy and guidelines of the journal and there are no conflicts of interest.

\section{REFERENCES}

1. Sumner J. The Natural History of Medicinal Plants, Timber Pres: London; 2000. p. 69.

2. Heinrich $\mathrm{M}$, Barnes $\mathrm{J}$, Gibbons $\mathrm{S}$, Williamson EM. Fundamentals of Pharmacognosy and Phytotherapy. UK: Churchill Livingston, Elsevier Science Ltd; 2004. p. 336.

3. Scurlock J. Sourcebook for Ancient Mesopotamian Medicine. Atlanta: SBL Press; 2014. p.786.

4. Samant SS, Dhar U, Palni LMS. Medicinal plants of IndianHimalaya: Diversity, distribution and potential value. Nainital: Gyano-daya Prakashan; 1998. p. 163.

5. Naser SH. Islamic Science-An illustrated study. Westerham. England: Westerham Press; 1976. p. 15.

6. Ahmad M, Khan MA, Marwat SK. Useful medicinal flora enlisted in Holy Quran and Ahadith. Am Eurasian J Agric Env Sci 2009;5(1):126-40.

7. Yari KH, Kazemi E, Yarani R, Tajehmiri A. Islamic Bioethics for Fetus Abortion in Iran. Am J Sci Res 2011;18:118-21.

8. Craig SR. Windhorses and Dharma Warriors: The Religious, Historical, and Cultural Significance of Horse Protection Rituals in Mustang, Nepal. In: Olsean SL, Littauer MA, Ingrid $\mathrm{R}$, editors. Horses and Humans: The Evolution of Humanequine Relationships BAR International Series: Oxford; 2006. p. 339-54.

9. Mark B. Duke's Handbook of Medicinal Plants of the Bible, HerbalGram. Austin, United States: American Botanical Council; 2010. p. 69.

10. Sharma S. Realms of Ayurveda. New Delhi: Arnold- Heineman; 1979.

11. Bhowmik D, Kumar KPS, Srivastava S, Paswan S, Sankar A, Dutta D. Traditional Indian herbs punarnava and its medicinal importance. J Pharmacogn Phytochem 2012;1:52-7. 
12. Tucakov J. Healing with plants - Phytotherapy. Beograd: Culture; 1971. pp. 180-90.

13. Jain SK, De Fillips RA. Medicinal Plants of India. vol. 2. Algonac (MI): Reference Publications; 1991. p. 558.

14. Varier PS. Indian Medicinal Plants. A Compendium of 500 Species. vol. 4. Hyderabad. India: Orient Longman; 1995. pp. 269-72.

15. Singh DK, Hajra PK. Floristic diversity. In: G.S. Gujral, V. Sharma V. Changing perspective of biodiversity status in the Himalaya, British Council Division, Wildlife Youth Services. New Delhi: British High Commission Publication; 1996. p. 23-38.

16. Sharma PV. Classical Uses of Medicinal Plants. Varanasi: Chaukhambha Visvabharati; 1996. p. 69-70.

17. Fakim-Gurib A. Medicinal plants: traditions of yesterday and drugs of tomorrow. Mol Aspect Med 2006:1-93.

18. Simbo DJ. An ethnobotanical survey of medicinal plants in Babungo. Northwest Region: Cameroon. J Ethnobiol Ethnomed 2010;6:1-7.

19. Chintamunnee V, Mahomoodally MF. Herbal medicine commonly used against infectious diseases in the tropical island of Mauritius. J Herb Med 2012;2:113-25.

20. Ekor M. The growing use of herbal medicines: issues relating to adverse reactions and challenges in monitoring safety. Front Phrmacol 2014;4:177

21. Joshi RK, Satya IP, Setzer WN. Himalayan aromatic medicinal plants: a review of their ethnopharmacology, volatile phytochemistry and biological activities. Medicines 2016;3(1):1-55.

22. Masood M, Arshad M, Qureshi R, Sabir S, Amjad MS, Qureshi H, Tahir Z. Picrorhiza kurroa: an ethnopharmacologically important plant species of the Himalayan region. Pure Appl Biol 2001;4:407-17.

23. Schippmann U, Leaman DJ, Cunningham AB. Impact of cultivation and gathering of medicinal plants on biodiversity, in: Global Trends and Issues, Biodiversity and the ecosystem approach in agriculture, forestry and fisheries. Rome: Commission on Genetic Resources for Food and Agriculture; 2002. p. 1-21.

24. Ramakrishnappa K. Impact of cultivation and gathering of medicinal plants on Biodiversity: Case studies from India, in: Biodiversity and the Ecosystem Approach in Agriculture, Forestry and Fisheries. 2002. Available from: http://www.wwf. org.uk/filelibrary/pdf/medplantsandcons.pdf

25. Wang L, Ren J, Zhe G. Current status and future direction of Chines herbal medicine. Trends Pharmacol Sci 2002;23:34848.

26. Hamilton AC. Medicinal plants, conservation and livelihoods. Biodiversity Conservation 2004;13:1477.

27. Sasidharan S, Chen Y, Saravanan D, Sundram KM, Yoga L. Extraction, isolation and characterization of bioactive compounds from plants extracts. Afr J Tradit Complement Altern Med 2011;8:1-10.

28. Petrovska BB. Historical review of medicinal plants usage. Pharmacog Rev 2012;6:1-5.

29. Mondal TK, Bantawa P, Sarkar B, Ghosh P, Chand PK. Cellular differentiation, regeneration, and secondary metabolite production in medicinal Picrorhiza spp. Plant Cell Tissues Organ Cult 2013;112(2):143-58.

30. Sah JN, Varshney VK. Chemical constituents of Picrorhiza genus: a Review. Am J Essential Oil 2013;1(2):22.

31. Kumar N, Kumar T, Sharma SK. Phytopharmacological review on genus Picrorhiza. Int J Universal Pharm Bio Sci 2013;2(4):334-47.

32. Katoch M, Fazli IS, Suri KA, Ahuja A, Qazi GN. Effect of altitude on picroside content in core collections of Picrorhiza kurrooa from the north western Himalayas. J Nat Med 2011;65:578-82.

33. Royle JF. Illustrations of the botany and other branches of the natural history of the Himalayan mountains and of the flora of Cashmere. New Delhi: Volume plates, Reprint, Today and Tomorrow's Printers and Publishers; 970. p. 71.

34. Coventry BO. Wild flowers of Kashmir Vol. 2. Dehradun: Reprint 1984. Bishen Singh Mahendra Pal Singh; 1927. p. 8990.

35. Barrie FR, Burdet HM, Chaloner WG, Demoulin V. International code of botanicals nomenclature, adopted by the fifteenth international botanical congress, Yokohana, Koeltz Scientific Books: Konigstein; 1994. p. 52-3.

36. Subedi B, Shretha R. Plant Profile. Himalayan. Bioresour 1999;3:14-15.

37. Polunin O, Stainton A. Flowers of the Himalayas. 6th ed. Delhi: Oxford University Press; 1990. p. 295.

38. Gaddipati JP, Madhavan S, Sidhu GS. Picroliv - a natural product protects cells and regulates the gene expression during hypoxia/reoxygenation. Mol Cell Biochem 1999;194:271-81.

39. Prajapati ND, Purohit SS, Sharma AK, Kumar T. A handbook of medicinal plants: A complete source book. Jodhpur, India: Agrobios; 2003. p. 396-97.

40. Singh GB, Sarang B, Singh S, Khajuria A, Sharma ML, Gupta BD, et al. Antiinflammatory activity of the iridoids kutkin,- picroside-1 and kutkoside from Picrorhiza kurrooa. Phytotherapy Res 2006;7:402-07.

41. Stuppner H, Wagner H. New cucurbitacin glycosides from Picrorhiza kurroa. Planta Med 1989;55:559-63.

42. Dorsch W, Stuppner H, Wagner H, Grapp M, Demoulin S, Ring J. Antiasthmatic effect of Picrorhiza kurroa: Androsin prevents Allergen and PFA- induced Branchial obstruction in Guinea pigs. Int Arch Allergy Immunol 1991;95:128-33.

43. Chettri N, Sharma E, Lama SD. Non-timber forest produces utilization, distribution and status in a trekking corridor of Sikkim. India. Lyonia 2005;8:94-108.

44. Bantawa P, Ghosh SK, Moitra S, Ghosh P, Mondal TK. Status and conservation threats of Picrorhiza scrophulariiflora Pennell. (Scrophulariaceae): An endangered high valued medicinal plant of the Indo-China Himalayan Region. Bioremed Biodiver Bioavail 2009;3:15-22.

45. Pennell FW. The Scrophulariaceae of the Western Himalayas. Reprint 1997. Dehradun, India: Bishen Singh Mahendra Pal Singh; 1943. p. 63-66.

46. Bantawa P, Saha-Roy O, Ghosh SK, Mondal TK. In vitro regeneration of an endangered medicinal plant Picrorhiza scrophulariiflora. Biol Plant 2011;55:169-72.

47. World Health Organization. African Traditional Medicine: African Technical Report Series No 1, Congo Brazaville: WHO Regional Office for Africa; 1976.

48. Maroyi A. An ethnopharmacological survey of medicinal plants used by the people in Nhema communal area. Zimbabwe. J Ethnopharmacol 2012;136(2):347-54.

49. Mahwasane ST, Middleton N, Boaduo N. An ethnobotanical survey of indigenous knowledge on medicinal plants used by traditional healers of the Lwamondo area: Limpopo province South Africa. S Afr J Bot 2013;88:69-75.

50. Kashyap SR. Samhita or Vriddha Jivakiya Tantra. Trans IGM Shastri. Mumbai, India: Bombey Sastu Sahitya; 1970. 
51. Gulabkunverba S. Charak Sutra 26, Charak Samhita. Jamnagar: India: Ayurvedic Society; 1949. p. 124-41.

52. Kirtikar KR, Basu BD. Indian Medicinal Plants. In: Harathi $\mathrm{K}$, Naidu CV, editors. Influence of Ethylene Inhibitor Silver Nitrate on Direct Shoot Regeneration from in Vitro Raised Shoot Tip Explants of Sphaeranthus indicus Linn.-An Important Antijaundice Medicinal Plant. Vol. III. Allahabad: Lalit Mohan Basu; 1935. p. 1825-26.

53. Chopra RN, Chopra IC, Handa KL, Kapur LD. Chopra's Indigenous Drugs of India, second edition. Calcutta: Dhur and Sons; 1981. pp. 181-83.

54. Chaturvedi GN, Singh RH. Jaundice of infections hepatitis and its treatment with an indigenous drug Picrorhiza kurroa. J Res Ind Med 1966;1:1-5.

55. Krishnamurthy A. The Wealth of India. New Delhi: Council of Industrial and Scientific Research; 1969. p. 49.

56. Weinges $\mathrm{K}, \mathrm{K}$ loss $\mathrm{P}$, Henkels WD Natural products from medicinal plants, XVII, Picroside -II, a new 6- Vanilloylcatapol from Picorhhiza kuroa Royle and Benth. Justus Liebigs Ann Chem 1972;759:173-82.

57. Nadkarni AK. "Indian Meteria Medica". Mumbai: Popular Parkashan Pvt. Ltd.; 1976. p. 953-954.

58. Pandey GS. Bhavaprakasa Nighantoo (Indian Materia Medica). Varanasi: India: Chaukhamba Sanskrit Sansthan; 1979. p. 70-71.

59. Dey AC. Indian Medicinal Plants Used in Ayurvedic Preparations. Dehradun, India: Bhishen Singh Mahendra Pal Singh; 1980. p. 11.

60. Langer JG, Gupta OP, Atal CK. Clinical trials Picrorhiza kurrooa as immunomodulator. Indian J Pharmacol 1981;13:9899.

61. Yegnarayan R, Dange SV, Vaidya SD, Balwani M. Study of Picrorhiza kurrooa (PK300) in case of bronchial asthma. Bombay Hosp J 1982;24:81-84.

62. Jayaweera DMA. Medicinal Plants Used in Ceylon, Part 5. Colombo. Sri Lanka: The National Science Council of Sri Lanka; 1982. p. 76.

63. Mogre K, Vora KK, Sheth UK. Effect of Picrorhiza kurroa and Eclipta alba on $\mathrm{Na}+\mathrm{K}+$ Atpase in hepatic injury by hepatotoxic agent. Indian J Pharmacol 1982;13:253-59.

64. Atal CK, Sharma ML, Kaul A, Kuajuria A. Immunomodulating agents of plant origin. I: Preliminary screening. J Ethnpharmacol 1986;18(2):133-41.

65. Ansari RA, Aswal BS, Chander R, Dhawan BN, Garg NK. Hepatoprotective activity of kutkin, the iridoid glycoside mixture of Picrorhiza kurroa. Indian J Med Res 1988;87:40104.

66. Zhang H, Zheng Z. Handbook of Chinese Traditional Medicine Resources. Beijing: Science Press; 1994. p. 1149.

67. Rajaram D. A preliminary clinical trial of Picrorhiza kurrooa in bronchial asthma. Bombay Hosp J 1996;18:66-69.

68. Luper S. A review of plants used in the treatment of liver disease: part 1. Altern Med Rev 1998;3(6):410-421.

69. Gupta PP. Picroliv Hepatoprotectant, immunomodulator. Drug Fut 2001;26:25-31

70. Anonymous. Ayurvedic interventions for diabetes mellitus: a systematic review. Altern Med Rev 2001;6:319-21.

71. Liu J, Liu BL, Zhang JQ, Zhang N. Hepatoprotective and choleretic action of Picrorhiza scrophulariae flora Pennell. Chin J New Drug 2002;11:459-61.

72. Zhang Y, DeWitt DL, David S, Muraleedharan NG. Cyclooxygenase-2 enzyme inhibitory triterpenoids from Picrorhiza kurroa seeds. Life Sci J 2005;77(25):3222-30.
73. Kala CP. Medicinal plants of the high altitude cold desert in India: Diversity, distribution and traditional uses. Int Bio Sci Manage; 2006;2:43-56.

74. Girish C, Pradhan SC. Drug development for liver diseases: Focus on picroliv, ellagic acid and curcumin. Fundam Clin Pharmacol 2008;22(6):623-32.

75. Bhandari P, Kumar N, Singh B, Ahuja PS. Online HPLCDPPH method for antioxidant activity of Picrorhiza kurroa Royle ex Benth and characterisation of kutkoside by ultraperformance LC electrospray ionization quadropole time of flight mass spectroscopy. Indian J Exp Biol 2009;48(3):32328.

76. Phondani PC, Maikhuri RK, Kala CP. Ethnoveterinary uses of medicinal plants among traditional herbal healers in alaknanda catchment of Uttarakhand, India. Afr J Tradit Complem 2010;7:195-206.

77. Bisht VK, Kandari LS, Negi JS, Bhandari AK, Sundriyal RC. Traditional use of medicinal plants in district Chamoli, Uttarakhand. India. J Med Plant Res 2013;7(15):918-29.

78. Ghisalberti EL. Biological and pharmalogical activity of naturally occurring iridoids and secoiridoids. Phytomedicine 1998;5(2):147-63.

79. State Pharmacopeia. Commission of P. R. China, Pharmacopeia of the P. R. China. Beijing: People's Health Publishing House; 1995. p. 204.

80. Zou ALC, Zhu TF, Gan SC, Wang DC, Zhang Y, Deng XM. Two new secoiridoid glycosides Zhongguo Yiyao Gongye Zazhi from the roots Picrorhiza scrophulariiflora. Chin Chem Lett 2008;19:1224-27.

81. Bhattacharjee S, Bhattacharya S, Jana S, Bhagel DS. A Review on Medicinally Important Species of Picrorhiza. Intl J Pharm Res Biosci 2013;2(4):1-16.

82. C P C Pharmacopoeia of the People's Republic of China, Beijing: Chemical Industry Press; 2005. p. 167.

83. GoyalBR,AgrawalBB, Goyal RK, MehtaAA. Pharmacological classification of herbal anti-asthmatics. Orient Pharm Exp Med 2007; 7:11-2580.

84. Lohani H, Gwari G, Andola HC, Chauhan N. High performance liquid chromatographic determination of Picroside I \& II in Picrorhiza kurroa Royle ex Benth: A critically endangered plant of Himalaya. Med Plants 2010;3:165-67.

85. Mohammed R, Mohammed U, Yamgar S, Gadgoli C, Salunkhe D. Preliminary screening and antimicrobial activity of Picrorhiza kurroa royle ethanolic extracts. Int J Pharm Sci Rev Res 2012;14(1):73-76.

86. Rathee D, Thanki M, Bhuva S, Anandjiwala S, Agrawal R. Iridoid glycosides-Kutkin, Picroside I and Kutkoside from Picrorrhiza kurroa Benth inhibits the invasion and migration of MCF-7 breast cancer cells through the down regulation of matrix metalloproteinases. Arab J Chem 2013;6(1):49-58.

87. Husain GM, Rai R, Rai G, Singh HB, Thakur AK, Kumar V. Potential mechanism of anti-diabetic activity of Picrorhiza kurroa. Tang 2014;4(4):1-5.

88. Kumar V, Sood H, Chauhan RS. Optimization of a preparative RP-HPLC method for isolation and purification of picrosides in Picrorhiza kurroa. J Plant Biochem Biot 2016;25(2):208-14.

89. Sultan AJ, Pervaiz Q. Phytochemical studies for quantitative estimation of iridoid glycosides in Picrorhiza kurroa Royle. Bot Stud 2016;57(7):4-6.

90. Kumar S, Patial V, Soni S, Sharma S, Pratap K, Kumar D, Padwad Y. Picrorhiza kurroa Enhances b-Cell Mass Proliferation and Insulin Secretion in Streptozotocin Evoked b-Cell Damage in Rat. Front Pharmacol 2017;8(537):1-15. 
91. Ali M, Sultana S, Mir Rasool S. Chemical Constituents from the Roots of Picrorhiza kurroa Royle Ex Benth. Int J Pharm Pharm Sci 2017;9(3):25-35.

92. Navya K, Kumar GP, Chandrasekhar Y, Kumar A. Evaluation of potassium dichromate ( $\mathrm{K} 2 \mathrm{Cr} 2 \mathrm{O} 7)$-induced liver oxidative stress and ameliorative effect of Picrorhiza kurroa extract in Wistar Albino Rats. Biol Trace Elem Res 2018;184:(1)15464.

93. Win NN, Kodamab T, Zar Khine LW, Winc YY, Ngwec H, Ikuro A, Hiroyuki M. Bis-iridoid and iridoid glycosides: Viral protein R inhibitors from Picrorhiza kurroa collected in Myanmar. Fitoterapia 2019;134:101-07.

94. Sacchettini JC, Poulter CD. Creating isoprenoid diversity. Science 1997;277:1788-1789.

95. Xie $\mathrm{Z}, \mathrm{Hu} \mathrm{H}$, Kong D, Yang $\mathrm{P}$ Two new compounds from Picrorhiza scrophulariiflora. Chin J Pharma 2007;38(3):22126.

96. Zou X, Liao X, Ding LS, Peng SL. Phenyl and phenylethyl glycosides from Picrorhiza scrophulariiflora. J Asian Nat Prod Res 2007;9(3-5):443-48.

97. Huang KY, He L, Qu Y, Gao HY, Deng XM, Wu LJ Isolation and identification of chemical constituents from roots of Picrorhiza scrophulariiflora Pennell. Shenyang Yaoke Daxue Xuebao 2009;26(2):112-15.

98. Zhu TF, Jiang K, Yan ZH, Hu JJ, Zou LC, Wang DC, Deng XM. A new secoiridoid glycoside from roots of Picrorhiza scrophulariiflora. Chin Herbal Med 2013;5(3):237-39.

99. Xiong K, Juc Z, Tong Z, Wangc Z, Han H. Metabolic profiles and pharmacokinetics of picroside $\mathrm{I}$ in rats by liquid chromatography combined with electrospray ionization tandem mass spectrometry. J Chromatogr B Analyt Technol Biomed Life Sci 2018;1095:157-65.

100. Kumar V, Sharma N, Shitiz K, Singh TR, Tan C, Sood H, Chauhan RS. An insight into conflux of metabolic traffic leading to picroside-I biosynthesis by tracking molecular time course changes in a medicinal herb, Picrorhiza kurroa. Plant Cell Tissue Organ Cult 2015;123:435-41.

101. Rajkumar V, Gunjan G, Kumar A; Antioxidant and anti-neoplastic activities of Picrorhiza kurroa extracts. Food Chem Toxicol 2011;49(2):363-69.

102. Mallick MN, Singh M, Parveen R, Khan W, Ahmad S, Najm MZ, Husain SA. HPTLC Analysis of Bioactivity Guided Anticancer Enriched Fraction of Hydroalcoholic Extract of Picrorhiza kurroa. BioMed Res Int 2015;1-18.

103. Hussain A, Shadma W, Maksood A, Ansari SH. Protective effects of Picrorhiza kurroa on cyclophosphamide-induced immunosuppression in mice. Pharmacog Res 2013;5(1):30-35.

104. Nagarathna PKM, Reena K, Reddy S, Wesley J. Review on immunomodulation and immunomodulatory activity of some herbal plants. Int J Pharmaceut Sci Rev Res 2013;22(1):22330 .

105. Shubha KS, Sumana K, Lakshmidevi L. Antifungal activity of Solanum xantocarpum Sch and Wend and Picrorhiza kurroa Royle ex Benth against some clinical dermatophytes. Int J Curr Microbiol Appl Sci 2016;5(2):236-44.

106. Sehgal R, Chauhan A, Gilhotra UK, Gilhotra A. In vitro and in vivo evaluation of antiasthmatic activity of Picrorhizz kurroa Plant. Int J Pharm Sci 2013.4(9):3440-43.

107. Turaskar A, More S, Sheikh R, Gadhpayle J, Bhongade SL. Inhibitory potential of Picrorhiza kurroa royle ex. benth extracts on phenylhydrazine induced reticulocytosis in rats. Asian J of Pharm Clin Res 2013;6(2):215-16.

108. Deshpande N, Das RK, Manohar M, Das V, Kandi S, Ramana KV. Antioxidant effects of Picrorhiza kurrooa rhizome extracts in alcoholic cirrhosis of liver. Am J Pharmacol Sci 2015;3(5):49-51.

109. Shaba P, Pandey NN, Sharma OP, Rao J, Singh RK. In vitro antitrypanosomal evaluation of Picrorhiza karroa rhizome. Int Res J Pharm 2012;3(7):205-08.

110. Morikawaa T, Nakanishia Y, Inouea H, Mansea Y, Matsuuraa $\mathrm{H}$, Hamasakia $\mathrm{S}$, et al. Acylated iridoid glycosides with hyaluronidase inhibitory activity from the rhizomes of Picrorhiza kurroa Royle ex Benth. Phytochemistry 2020;169:112-85.

111. An N, Wang D, Zhu T, Zeng S, Cao Y, Cui J, et al. Effects of scrocaffeside A from Picrorhiza Scrophulariiflora on immunocyte function in vitro. Immunopharmacol Immunotoxicol 2009;31(3):451-58.

112. Xu X, Wang W, Zhao Z, Xi W, Yu B, Hao C, et al. Effects of total iridoid glycosides of Picrorhiza scrophulariiflora against non-alcoholic steatohepatitis rats induced by high-fat and high-sugar diet through regulation of lipid metabolism. Chin Herb Med 2020;42:1-6.

113. Firdous J, Bharathi V, Muhamad N, Zaini F. Evaluation of anti-microbial activity in Picrorhiza kurroa plant extract using thin-layer chromatography and FTIR. Int J Pharm Tech 2016;8(3):15717-722.

114. Zou L, Yan Z, Zhu T, Xiang H, Wang D. Two new phenylethanoid glycosides and a new secoiridoid glycoside from the roots of Picrorhiza scrophulariiflora. Chin Chem Lett 2010;21:1103-06.

115. Zhu T, Chen J, Yang Y, Sun Q, Hu L, Yan ZH, Li P. Secoiridoid glycosides from the roots of Picrorhiza scrophulariiflora. Chem Nat Compd 2018;54(4):23.

116. Wang H, Zhao W, Choomuenwai V, Andrews K, Quinn R, Feng Y. Chemical investigation of an antimalarial Chinese medicinal herb Picrorhiza scrophulariiflora. Bioorg Med Chem Lett 2013;23:5915-18.

117. Usman M, Surekha Y, Chhaya G, Devendra S. Preliminary screening and antimicrobial activity of Picrorhiza kurroa Royle ethanol extracts. Int J Pharm Sci Rev Res 2012;14:7376.

118. Rathee D, Rathee P, Rathee S, Rathee D. Phytochemical screening and antimicrobial activity of Picrorrhiza kurroa, an Indian traditional plant used to treat chronic diarrhea. Arab J Chem 2016;9:1307-13

119. Kumar R, GuptaYK, Singh S, Arunraja S. Picrorhiza kurroa inhibits experimental arthritis through inhibition of Proinflammatory Cytokines, Angiogenesis and MMP. Phytother Res 2016;30:112-19.

120. Krupashree K, Kumar K, Rachitha P, Jayashree GV, Khanum F. Chemical composition, antioxidant and macromolecule damage protective effects of Picrorhiza kurroa Royle ex Benth. S Afr J Bot 2014;94:249-54.

121. Cao X, Qiao J, Wang L, Ye X, Zheng L, Jiang N, Mo W. Screening of glycoside isomers in P. scrophulariiflora using ionic liquid-based ultrasonic-assisted extraction and ultraperformance liquid chromatography/electrospray ionization quadruple time-of-flight tandem mass spectrometry. Rapid Commun Mass Spectrom 2012;26:740-48. 
122. Chen Z, Wu J, Shen W, Liu P, Cao Y, Lu Y. Counter-current chromatographic method for preparative scale isolation of picrosides from traditional Chinese medicine Picrorhiza scrophulariiflora. J Separation Sci 2011;34(15):1910-16.
123. Tiwari SS, Pandey MM, Srivastava S, Rawat AKS. TLC densitometric quantification of picrosides (picroside-I and picroside-II) in Picrorhiza kurroa and its substitute Picrorhiza scrophulariiflora and their antioxidant studies. Biomed Chromatogr 2012;26:61-68. 